\title{
Model for the performance of photovoltaic systems
}

\section{Amaury de Souza}

Universidade Federal de Mato Grosso do Sul. Instituto de Física. Caixa Postal 549. Campo Grande-MS, Brazil (CEP 79090-900). Email: amaury.de@uol.com.br.

Abstract. In this article, the future in photovoltaic energy productivity (PVE) is evaluated using climate variables simulated aerosol clearness index and solar irradiance, it is a model for the performance of photovoltaic systems. The analysis indicates that the aerosol emission reductions in the near future result in an increase in global warming with a significant response of the solar surface radiation and associated PVE productivity. Changes in radiation surface and productivity of solar PVE are related to overall reduction in aerosol effects on the circulation and large scale associated with cloud coverage pattern, rather than local atmospheric effects on optical properties. PVE evaluation is then discussed in the context of the current situation and the PV market highlighting the effects on productivity induced by industrial and public policies, while technological development are comparable to the effects related to the weather. The results presented encourage the improvement and further use of climate models in the assessment of future availability for renewable energy.

Keywords: Climate change; Emissions; Energy systems vulnerability; Impacts and risks; Renewable energy.

Resumo. Modelo para o desempenho de sistemas fotovoltaicos. Neste artigo, o futuro da produtividade de energia fotovoltaica (PVE) é avaliado usando variáveis climáticas, índice de nitidez de aerossol e irradiância solar, em um modelo para o desempenho de sistemas fotovoltaicos. A análise indica que as reduções de emissões de aerossóis no futuro próximo resultam em um aumento no aquecimento global com uma resposta significativa da radiação da superfície solar e da produtividade PVE associada. Mudanças na superfície de radiação e na produtividade do PVE solar estão relacionadas à redução geral dos efeitos de aerossóis na circulação e em grande escala associados ao padrão de cobertura de nuvens, ao invés de efeitos atmosféricos locais nas propriedades ópticas. A avaliação do PVE é então discutida no contexto da situação atual e do mercado de PV destacando os efeitos sobre a produtividade induzidos pelas políticas públicas e industriais, enquanto o desenvolvimento tecnológico é comparável aos efeitos relacionados ao clima. Os resultados apresentados incentivam a melhoria e o uso futuro de modelos climáticos na avaliação da disponibilidade futura de energia renovável.
Received:

November 14, 2018

Accepted:

December 29, 2018

Released:

December 31, 2018

Full Text Article

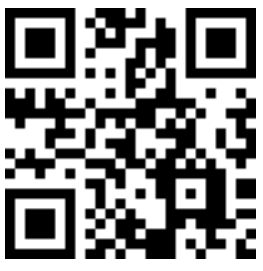

ORCID

다 0000-0001-8168-1482

Amaury de Souza 
Palavras-chave: Mudanças climáticas; Emissões; Vulnerabilidade dos sistemas energéticos; Impactos e riscos; Energia renovável.

\section{Introduction}

Photovoltaic systems allow the conversion of solar energy into electricity from sunlight, it is the growing demand for electricity worldwide and one of the sustainable solution alternatives. This clean technology has inspired many researchers who have studied the performance of different systems with the goal of maximizing PV production at the lowest cost. Skoplaki and Palyvos (2009) were interested in another parameter, that is, the operating temperature of cells and solar modules, they presented different correlations as to their effect on the electrical performance of photovoltaic installations. Other works like Razykov et al. (2011), Parida et al. (2011), El-Chaar et al. (2011) and Si et al. (2017) focused on the progress made in the different photovoltaic technologies, and particularly on the effect of solar cell materials.

In other experimental investigations like in the works of Ryu et al. (2006) and Wu et al. (2012), different configurations of solar photovoltaic concentration systems using Fresnel lenses have been proposed and tested under different operating parameters such as solar radiation intensity, ambient air temperature and natural and forced convection. Another new technology in which high flux photovoltaic cells were used for different solar cell concentrator designs was proposed by Feuermann and Gordon (2001). These authors proposed a new approach to the concentration of photovoltaic systems that can easily reach the maximum flow level compatible with solar cell technology. In addition, the same techniques can be incorporated into improved photovoltaic performance models of more accurate energy efficiency forecasts.

Energy systems may be vulnerable to climate change, Schaeffer et al. (2012) presented an assessment of the impacts that climate change may have on the energy chain and identifies knowledge gaps and areas for the development of future research. One of the biggest challenges is how to assess the impacts that can occur as a consequence of the projected increase in the intensity of extreme weather events: most current methodologies rely on past experience, but this may not be a good enough guide for operational activity planning in the coming decades. In addition, climate impact assessments on energy planning and operation need to take into account a larger number of scenarios as well as investigate impacts on specific energy segments. Therefore, there is a need to identify the energy segments for which research has been conducted with little impact on the climate. Finally, because the climate impact assessment for energy systems is a relatively new field of research, it is expected that methodological developments will increase in the near future with the consequent expansion of the knowledge based on the subject.

Clouds mainly influence the performance variability of photovoltaic systems but variations also exist for days with clear sky with different amounts of atmospheric constituents that absorb and reflect different amounts of radiation passing through Earth's atmosphere. The extent of the attenuation is determined by the mass of air, the amounts of water vapor and aerosols which constitute the ozone of the atmosphere for a given day and location.

Because these components selectively absorb radiation of specific wavelengths, their impact on PV performance is sensitive to the spectral response of the photovoltaic device. Although, impacts are generally small, they may exhibit seasonal or geographic trends that increase variability in PV performance measurements from season 
to season, by location, or in some cases from day to day.

The relationship between renewable energies (RE) and climate has often been investigated from the perspective of the global climate impact resulting from increased penetration of renewable sources in the global energy matrix and the associated reduction in carbon dioxide emissions (IPCC, 2011; UNECA, 2011). The possibility of totally replacing pre-existing energy explored by Jacobson and Delucchi (2011) and Delucchi and Jacobson (2011) suggests that the barriers to the development of such a plan are mainly social and political (Jacobson and Archer, 2012). On the other hand, the technological and economic limits for the high penetration of ER in the electric power system still exist mainly on the storage, network flexibility and energy necessary to incorporate the generation of electricity from intermittent sources in the transport network (Denholm et al., 2010; Denholm and Hand, 2011).

However, the relationship has a second meaning as well, as climate change is also expected to act on the meteorological variables ultimately regulating the availability and geographic location of the various renewable resources. The scientific literature on this subject is relatively scarce and the IPCC itself has indicated that "climate change will have an impact on the size and geographical distribution of the technical potential of renewable energy sources, but research into the magnitude of these possible effects is incipient" (IPCC, 2011).

With expectations generated by photovoltaic solar modules showing rapid growth and consequent investments being mobilized by the photovoltaic sector, it makes sense to analyze how and to what extent current photovoltaic potential could be affected in the coming decades by expected changes in weather patterns both in terms of energy production and infrastructure vulnerability (Patt et al.,
2013). However, despite growing interest, few studies have directly investigated the impact of climate change on photovoltaic energy production compared to other renewable sources such as hydropower and wind (Schaeffer et al., 2011; Souza et al., 2016; Souza and Aristone, 2017, 2018). Some studies based on projections of climate models estimate an increase in Europe by the end of the 21st century (Pašičko et al., 2012; Wachsmuth et al., 2013; Dowling, 2013), a few percent increase in China, and a few percent decrease in the US West and Saudi Arabia (Crook et al., 2011).

The PVE productivity is related to the solar radiation and the surface temperature of the photovoltaic modules. Solar radiation and temperature are in turn affected by the optical properties of the atmosphere and in particular, their aerosol content. In fact, aerosols interact directly with solar radiation through dispersion and absorption (Angeströem, 1962), and leads to temperature changes with consequent evaporation of cloud droplets (Hansen et al., 1997). In addition, aerosols affect cloud properties by increasing cloud albedo by increasing the number of cloud droplets (Twomey, 1997), and extending cloud life by forming droplets smaller than reduce the likelihood of precipitation (Albrecht, 1989).

Understanding the chemistry and dynamics of aerosols and their inclusion in climate models are key steps in improving the description of climate variability (Brasseur et al., 2003). In the context of climate change, a realistic simulation of the rising temperature trend observed throughout the 20th century is only possible considering the combined impact of anthropogenic greenhouse gases (GHG) and aerosol emissions (Roeckner et al., 1993). In particular, a reliable assessment of climate change in the short term, that is, the next 20-30 years requires climate models capable of correctly including the 
role of aerosols because of the short atmospheric life of aerosols and because aerosol emissions and precursor aerosols are nowadays more effectively regulated by GHG (Kloster et al., 2008, 2010; Raes and Seinfeld, 2009). Shortterm climate change and the role of aerosols are particularly relevant for the assessment of future PVE resources where exploitation is based on technologies with years of life 20-30 (Skoczek et al., 2009; Jordan and Kurtz, 2013) and strongly affected by the radiative properties of the atmosphere.

The environmental changes arising from the process of land occupation with burning emissions are also an important focus. The forest interacts strongly with the atmosphere, emitting and absorbing gases and particles, and thereby altering the physical, chemical and biological environment of the ecosystem. Aerosol particles are emitted naturally by vegetation and these are critical in the mechanisms of cloud production, solar radiation balance and nutrient cycling, among other processes. Understanding the natural processes that regulate the composition of the atmosphere is critical for developing a sustainable development strategy in the region. As a result of the emissions of fires, the atmospheric concentrations of aerosol particles and trace gases increase by factors from 2 to 8 in large areas which changes the radiation balance with the absorption of up to $70 \%$ of the photosynthetically active radiation. This reduction in radiative flux affects the photosynthetic rate, surface temperature and latent and sensitive heat fluxes. The deposition of nutrients is strongly affected by anthropic action with significant increase of nitrogen deposition in altered areas (Artaxo et al., 2006).

The objective of this work is to evaluate the availability of PVE with a focus on the sensitivity of PVE resources with concentrations of anthropogenic aerosols and clarity index. PVE is estimated through a model for photovoltaic performance which uses as input the data of radiation and temperature of the cells, wind velocity and atmospheric clarity index.

\section{Materials and methods}

\section{Characterization of the photovoltaic system}

The photovoltaic system studied consists of three $100 \mathrm{Wp}$ photovoltaic modules connected in parallel, installed with their faces facing the geographical north and with a slope angle of $33^{\circ}$ (Latitude $+10^{\circ}$ ). The module used has technical specifications described by the manufacturer for the standard condition of operation, solar radiation of 1,000 W. $\mathrm{m}^{-2}$ and temperature of $25{ }^{\circ} \mathrm{C}$ subject to variations of $10 \%$ and an average daily insolation of $4 \mathrm{~h}$ and a half peak.

Electrical characteristics $(1,000$ $\left.\mathrm{W} . \mathrm{m}^{-2}, 25{ }^{\circ} \mathrm{C}, \mathrm{AM} 1.5\right)$ : Rated voltage (Vn) - $12 \mathrm{~V}$; Maximum power (Pmp) - $100 \mathrm{Wp}$; Short circuit current (Isc) - 6.54A; Open Circuit Voltage (Voc) - 21.6 V; Maximum Power Current (Imp) - 5.74 A; Maximum power voltage (Vmp) - $17.4 \mathrm{~V}$; Physical characteristics: Number of cells in series - 36; Number of cells in parallel - 2; Dimensions C x W x H (mm) - 1,310 x $652 \times 33.8 \mathrm{~mm}$; Weight (kg) - $11 \mathrm{~kg}$; TON - (800 W.m-2, $20{ }^{\circ} \mathrm{C}$, AM 1.5).

\section{collection \\ Measurements and data}

To determine the efficiency of the photovoltaic system, the following measurements of the electrical and meteorological parameters pertinent to the system were necessary: Open system voltage (Voc) in Volts; System shortcircuit current (Isc) in Amps; Irradiance $\mathrm{Gi}$ - parallel to the plane of the modules $\left(33^{\circ}\right)$ in W.m ${ }^{-2}$; Gh - in the horizontal plane (in $\mathrm{Wm}^{-2}$ ); Temperatures in the Tc system - surface temperature (glass) of the modules which was considered as the temperature in the cell (in $\left.{ }^{\circ} \mathrm{C}\right)$; $\mathrm{Ta}$ - room temperature $\left({ }^{\circ} \mathrm{C}\right)$; Wind speed $(\mathrm{Vv})$, in $\mathrm{m} . \mathrm{s}^{-1}$. 
To carry out measurements of the electrical parameters, a control system was developed through relays to disconnect the load from the photovoltaic modules and obtain the open circuit voltage. To obtain the shortcircuit current, the short-circuit of the modules was made. These measurements were taken at $1 \mathrm{~h}$ intervals. The data were collected and stored by the meteorological sensors: rain gauge, pyranometer, anemometer, thermometer to measure the ambient temperature and the module (cell), electric sensors to measure the open circuit voltage and the short circuit current of the modules and currents and voltages in and out of load controllers and inverters. A datalogger was used.

The datalogger was also used to control the opening and closing of the relays in order to read the open circuit voltage and short circuit current of the modules. The system has been programmed to perform $10 \mathrm{~s}$ readings of the meteorological data and to display the average of the values at one hour intervals. The readings of the open circuit voltage and the short circuit current of the photovoltaic modules were also carried out every hour. In order to predict the energy production of photovoltaic modules, it is necessary to predict the temperature of the module as a function of wind speed, brightness index, total irradiance and aerosols.

The dependent variable $(\mathrm{Y})$ is the temperature coefficients of the cells and as independent variables $(\mathrm{X})$, the study days. The transformation of the day variable into the year-centered variable (year minus the midpoint of the study period) became necessary since in polynomial regression models, the terms of the equation are often highly correlated and the independent variables expressed as a deviation from their mean reduces substantially to the selfcorrelation between them. A trend analysis of the historical series was performed using a multiple linear regression model that best described the relationship between the independent variables X's (irradiance, wind velocity, lightness index and optical depth) and the dependent variable Y cells.

Using the equation:

$$
Y=\beta_{0}+\beta_{1} X_{1}+\beta_{2} X_{2}+\ldots+\beta_{k} X_{k}+e
$$

where $k$ is number of variables; $X_{j}$ are regressors; $\beta_{j}$ are estimators; $e$ is the random error and $j=1,2, \ldots, k$.

As a measure of precision, the coefficient of determination $\left(\mathrm{R}^{2}\right)$ was used. The analysis of the residues confirmed the homoscedasticity assumption of the model (Montgomery and Peak, 1992; Latorre and Cardoso, 2001).

Optical depth data were obtained from Aerosol Robotic Network (AERONET); a remote sensing aerosol monitoring network operated by NASA and LOA-Photons. In Brazil, the program has nine stations operated by INPE and
IAG/USP. The program provides a continuous and long-term database of microphysical and radiometric properties of aerosols for aerosol-related research, satellite image corrections and relationships with other databases (Holben et al., 1998). The measurements of solar radiation on the surface are carried out through a Cimel 318 electronic solar photometer that performs measurements of direct and diffuse radiation on the $340,380,440$, $500,675,870$ and $1,020 \mathrm{~nm}$ channels in various angular directions every $15 \mathrm{~min}$ and in certain predetermined zenith and azimuth positions. It has two collimators, one for direct radiation measurements and the other for diffuse radiation 
coupled to the sensor head where a wheel is positioned that accommodates the sensor filters for the various measuring wavelengths.

The head of the sensor is coupled to a zenithal and azimuthal motor that direct the collimators to predetermined positions relative to the positioning of the Sun. From the data, direct solar radiation on the surface and the values of solar radiation at the top of the atmosphere are known. The term ' $u$ ' is related to the trajectory of radiation in the Earth's atmosphere and depends on the zenithal angle of measurement in the plane of the solar trajectory. Once these three terms are known, the optical depth parameter $\tau \lambda$ can be indirectly established (Echer et al., 2001).

According to Vermote and Vermeulen (1999), the performance of aerosols in attenuation of solar radiation is more significant in the $500 \mathrm{~nm}$ channel. This fact justifies the use of optical depth at this wavelength when it is sought to consider the action of aerosols in radiative transfer models. Considering this aspect, we will use the optical depth of aerosols in the channel of $500 \mathrm{~nm} \tau 500 \mathrm{~nm}$ as indicative of atmosphere contaminated by aerosols in this research.

The lightness index (Kt) determines the sky coverage defined as the ratio between the incident solar radiation (Rg) (MJ. $\mathrm{m}^{-2}$. day $\left.{ }^{-1}\right)$ and the radiation at the top of the atmosphere (Ro) (MJ.m ${ }^{-2} \cdot$ day $\left.^{-1}\right)$. The expression is givem as:

$$
K_{t}=\frac{R_{g}}{R_{o}}
$$

The clarity index (Kt) was determined by the sky cover type according to the methodology of Ricieri
(1998), in which in the interval $0<\mathrm{Kt}<$ 0.3 , the global and diffuse radiations are practically the same and the radiation direct approach is close to zero, classifying the sky under these conditions as cloudy. For $0.3 \leq \mathrm{Kt} \leq 0.65$, the radiations, diffuse and direct remain close denominating of partly cloudy sky. And between $0.65<\mathrm{Kt}<1.0$, the direct radiation approaches the global, while the diffuse tends to the minimum in these conditions denominated by clear sky.

In this study, multiple linear regression equation (MLR) and principal component analysis (PCA) were combined to perform the PCR analysis. This PCR model was adopted to predict the future of energy demand. Brief description of PCA, MLR and PCR are subsequently given as follows.

Principal component analysis transforms the original data set of ' $n$ ' variables that are correlated to each other in varying degrees for a new dataset containing ' $\mathrm{n}$ ' number of uncorrelated main components (PCs). PCs are linear functions of the original variables in a way that the sum of the deviations is equal for both the original and new variables. PCs are sequenced from the highest variance to the lowest. The first PC explains the largest amount of variance of the data. The next largest variance is explained by the second $\mathrm{PC}$ and so on for all ' $n$ ' PCs. The values of all PCs can be obtained by the same equation as equations 3 and 4 . These two equations are for a PC1 and PC2. Although the number of computers and original variables are equal, usually most of the variance of the data set can be explained by the first computers that can be used to represent the original observations (Abdul-Wahab et al., 2005; Olsen et al., 2012). This helps reduce the dimensionality of the original dataset. 


$$
\begin{aligned}
& P C_{1}=a_{11} x_{1}+a_{12} x_{2}+\ldots+a_{1 n} x_{n}=\sum_{j=1}^{n} a_{1 j} x_{j} \\
& P C_{2}=a_{21} x_{1}+a_{22} x_{2}+\ldots+a_{2 n} x_{n}=\sum_{j=1}^{n} a_{2 j} x_{j}
\end{aligned}
$$

Where $x_{1}, x_{2}, \ldots, x_{n}$ are the original variables in the data set and $j j$ are the eigenvectors.

The eigenvalues are the variances of the PCs and the $a_{j j}$ coefficients are the eigenvectors extracted from the covariance or matrix correlation of the data set.

The eigenvalues of the data matrix can be calculated by Equation (5) as:

$$
|\mathrm{C}-\lambda \mathrm{I}|=0
$$

Where ' $\mathrm{C}$ ' is the correlation/covariance matrix, $\lambda$ is the eigenvalue and $I$ is the identity matrix.

The PC coefficients or the weights of the variables in the PC are then calculated by Equation (6):

$$
|\mathrm{C}-\lambda \mathrm{I}| a_{j j}=0
$$

Due to the differences in the units of the energy demand variables used in this study, a correlation matrix of the variables was used to obtain values and their own vectors. The proper vectors multiplied by the square root of the eigenvalues produce a $n \times n$ matrix of coefficients which are called variable loads. The importance of each original variable for a particular PC is represented by these loads. In addition, the sum of the products of the variable loads and the values of the original variables produce a new set of data values that are called punctuation of the components. These results can be used in the various linear equations as new variables to predict the future of energy demand.

The multiple regression analysis to model the relationship between two or more independent variables with a dependent variable fitting a linear equation for the observed data. The general equation of an MLR model can be expressed as below:

$$
y=a_{0}+a_{1} x_{1}+a_{2} x_{2}+\ldots+a_{n} x_{n}
$$

Where $Y$ is the dependent variable, $a_{i}(i=0,1, \ldots, n)$ are generally the parameters estimated by the least squares method and $x_{i}(i=1,2, \ldots, n)$ are the independent variables.

\section{Principal components of regression (PCR)}

In the PCR analysis, MLR and PCA are combined together to establish a relationship between the dependent variable and the selected PCs of the input variables (Pires et al., 2008). Mainly, major components obtained from the ACP are taken as the independent variable in the multiple linear regression equation to perform the PCR analysis. The general equation of the PCR model is: 


$$
Y=a_{1} \times P C_{1}+a_{2} \times P C_{2}+\ldots+a_{n} \times P C_{n}
$$

\section{Results and discussion}

The values of the cell temperature distribution, solar irradiation over a horizontal plane, the clarity index and the aerosols in 2013 are plotted in Figure 1. These values were used to predict the temperature of the PV cell.

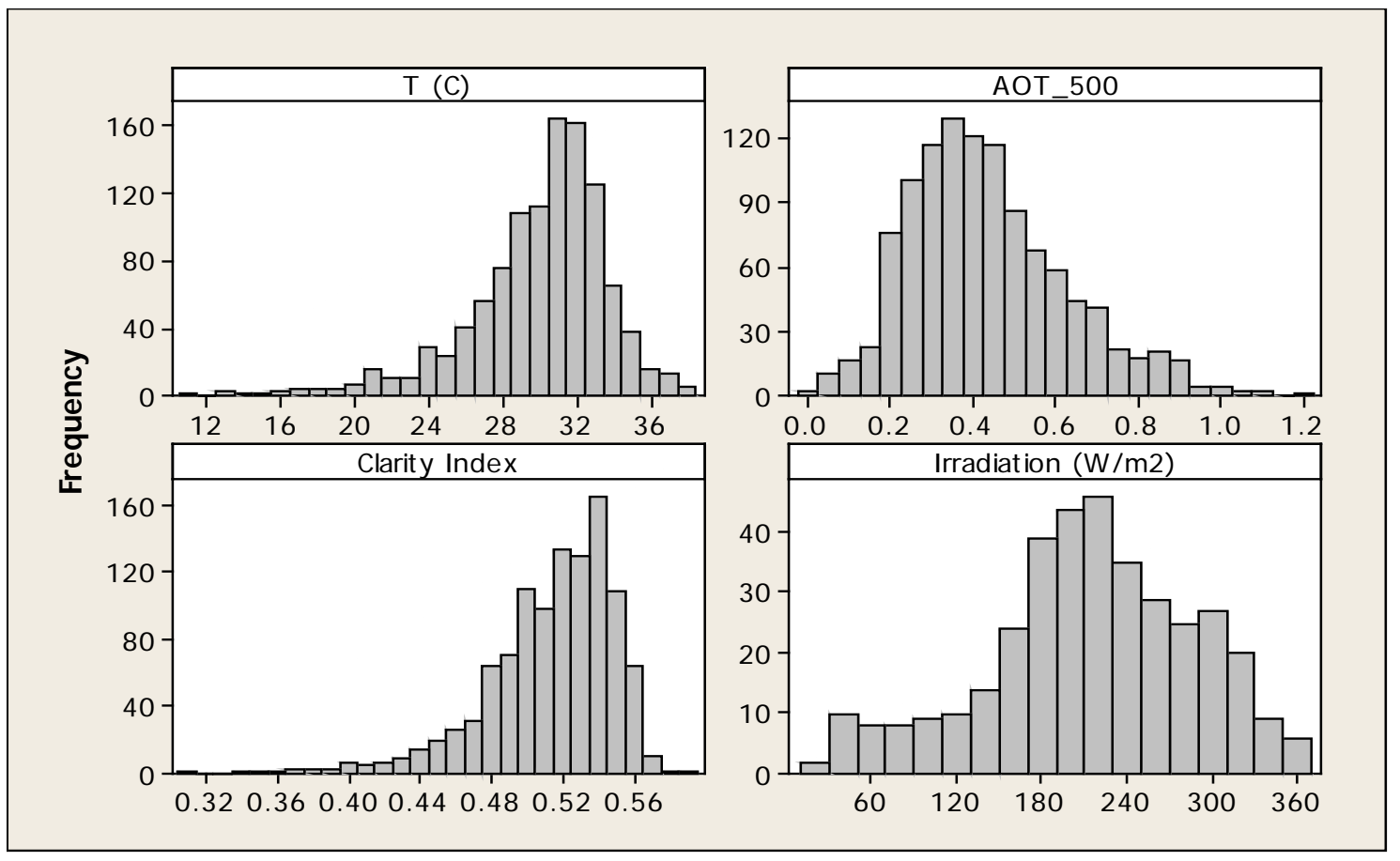

Figure 1. Frequency of cell temperature distribution $\left({ }^{\circ} \mathrm{C}\right)$, solar irradiation $\left(\mathrm{W} \cdot \mathrm{m}^{-}{ }^{2}\right)$, clarity index and AOT for the year 2013.

To evaluate the adjustment of the model, a residual analysis must be performed. This analysis can be done through the graph of the residual variances of each observation in relation to the values adjusted by the model. The model defined the graph with the points closest to zero in the range of -5.0 to +5.0 (Figures 2 and 3). Another graph that is also a good indicator of fit of the model is the observed values of the response variable in relation to the values defined by the model. The points in this graph should be close; indicating that the adjusted values are close to measured values (Figures 2 and 3) (Souza et al., 2013; Souza et al., 2015).

The temperature of the photovoltaic cells is one of the most important parameters used in the evaluation of the performance of photovoltaic systems and their power. The efficiency of the photovoltaic module depends to a large extent on the operating temperature of its cells. PV cell temperatures are very difficult to 
measure since the cells are tightly encapsulated to protect them from degradation caused by continuous exposure to time (Trinuruk et al., 2009).
A descriptive analysis of the variables is presented in Table 1 while the result for the regression analysis is presented in Table 2 .

Table 1. Descriptive analysis of the values: Cell temperature $\left({ }^{\circ} \mathrm{C}\right)$, solar irradiance $\left(\mathrm{W} / \mathrm{m}^{2}\right)$, wind velocity $(\mathrm{m} / \mathrm{s})$, Clarity index and AOT and measured days.

\begin{tabular}{lccccc}
\hline & Tmeasure C & $\begin{array}{c}\text { Irradiation } \\
\left(\mathbf{W} / \mathbf{m}^{\mathbf{2}}\right)\end{array}$ & $\begin{array}{c}\text { Velocity } \\
(\mathbf{m} / \mathbf{s})\end{array}$ & $\begin{array}{c}\text { Index } \\
\text { clarity }\end{array}$ & A0T_500 \\
\hline Average & 26.23 & 214.11 & 3.016 & 0.50589 & 0.139288 \\
Standard deviation & 4.59 & 73.96 & 1.24 & 0.04305 & 0.110058 \\
Coefficient of & & & & & \\
variation & 17.48 & 34.54 & 41.35 & 8.50996 & 79.0146 \\
Minimum & 11.82 & 14.02 & 0 & 0.36 & 0 \\
Maximum & 35.35 & 361.46 & 7.6 & 0.58 & 0.56 \\
Observations & 365 & 365 & 365 & 365 & 365 \\
\hline
\end{tabular}

Table 2. Regression analysis of the values by the Linear Regression Model (MRL) and Principal Component Analysis (ACP).

\begin{tabular}{|c|c|c|c|c|c|c|c|c|c|}
\hline \multicolumn{5}{|c|}{ MRL } & \multicolumn{5}{|c|}{ PCR } \\
\hline S & R-sq & R-sq(adj & R-sq(pred) & error & S & R-sq & R-sq(adj & $\begin{array}{l}\text { R-sq } \\
\text { (pred) }\end{array}$ & Error \\
\hline 166.404 & $87.98 \%$ & $87.86 \%$ & $87.62 \%$ & 5,25 & 166.662 & $87.95 \%$ & $87.82 \%$ & $87.58 \%$ & 4,53 \\
\hline coefficients & \multicolumn{9}{|c|}{ coefficients } \\
\hline & coef & SE Coef & T-Value & P-Value & \multirow{3}{*}{$\begin{array}{c}\text { constant } \\
\text { PC1 }\end{array}$} & coef & SE Coef & T-Value & P-Value \\
\hline constant & -19.65 & 1.09 & -17.98 & 0.000 & & 262.348 & 0.0974 & 269.40 & 0.000 \\
\hline $\begin{array}{l}\text { Irradiation } \\
\left(\mathrm{W} \cdot \mathrm{m}^{-2}\right)\end{array}$ & 0.01796 & 0.00144 & 12.51 & 0.000 & & 11.053 & 0.0709 & 15.58 & 0.000 \\
\hline index clarity & 79.43 & 2.26 & 35.16 & 0.000 & PC2 & 34.418 & 0.0850 & 40.48 & 0.000 \\
\hline AOT_500 & 13.388 & 0.868 & 15.42 & 0.000 & PC3 & 1.555 & 0.116 & 13.40 & 0.000 \\
\hline
\end{tabular}


Regression equation by the Linear Regression Model (MRL)

Tmeasured C $=-19.65+0.01796$ irrad W.m ${ }^{2}+79.43$ ind clarity + 13.388 AOT_500

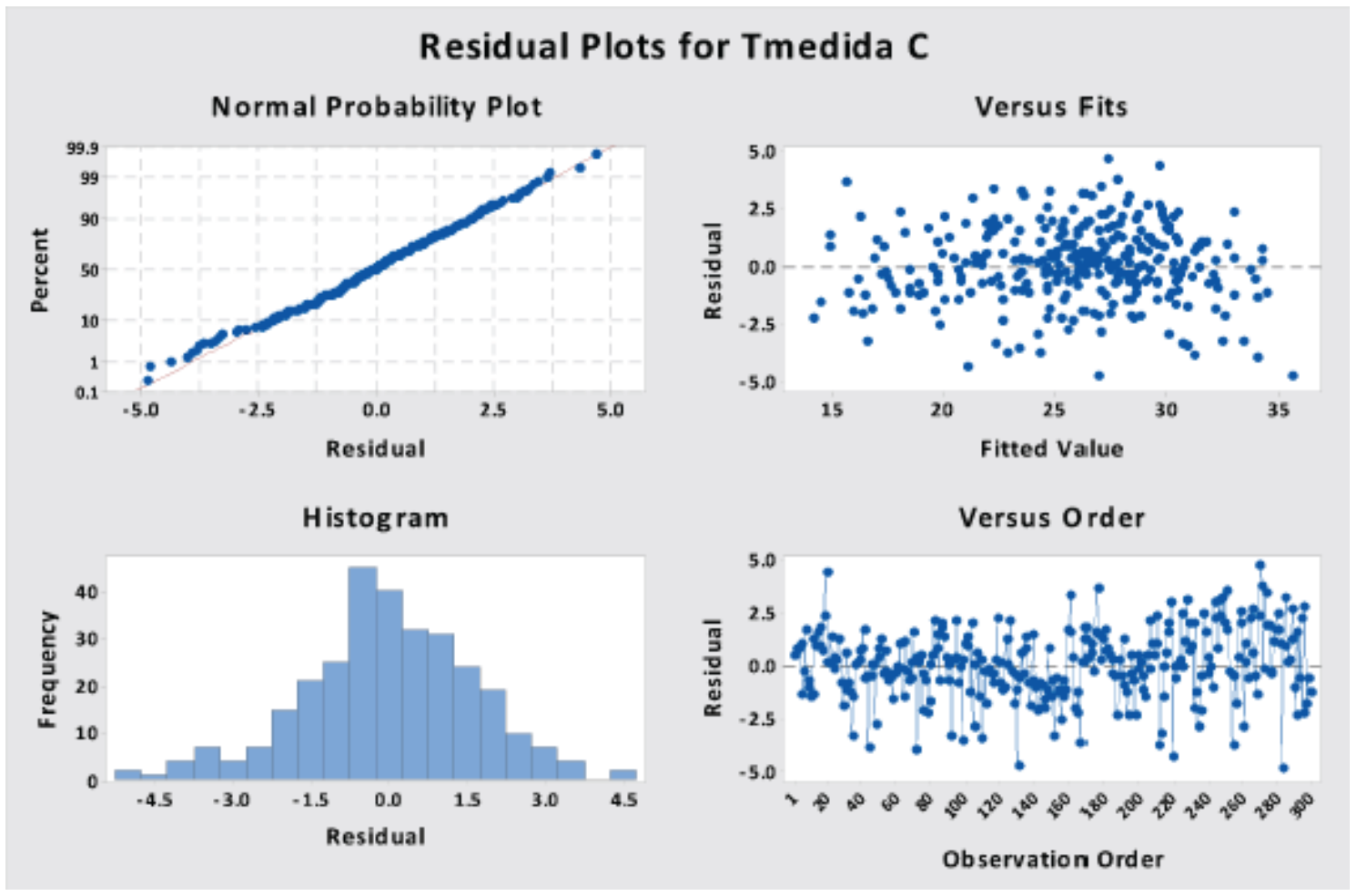

Figure 2. Modeling of temperature calculated as a function of irradiance, clarity index and aerosols by multiple regression analysis.

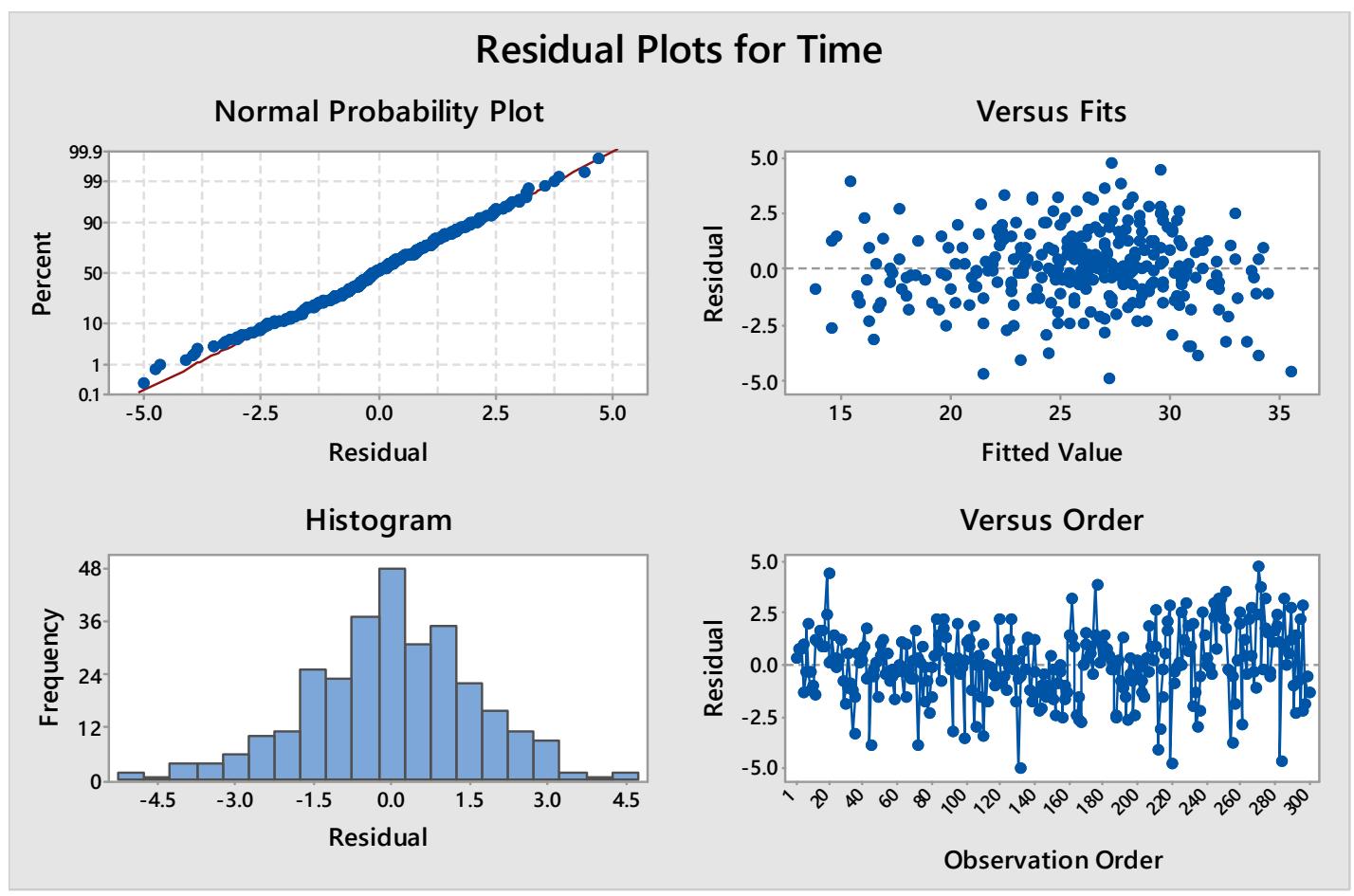

Figure 3. Modeling of temperature calculated as a function of irradiance, clarity index and aerosols by analysis of main components. 


\section{Regression Equation by Principal Component Analysis (ACP)}

Tmeasured $=26.2348+1.1053$

$\mathrm{PC}_{1}+3.4418 \mathrm{PC}_{2}+1.555 \mathrm{PC}_{3}$

Remark: Wind speed is not statistically significant

The Comparison between main component analysis and linear regression is as shown in Figure 4.

In this study, the precision of the model was determined using the data measured in Campo Grande, Mato Grosso State, Brazil, between January and December 2013. Using the data obtained, the regression coefficients were determined using curve fitting tools provided by the MATLAB software. The temperature prediction of the PV cell was developed using experimental data obtained during the analysis period of the study area based on the temperature prediction model described by MLR and PCR.

According to the results of the statistical test, it can be seen that the estimated values of the PV cell temperature using the model are in agreement with the measured values. Figure 4 shows the estimated values of the PV cell temperature used during the last 65 days of 2013. Temperatures reached daily maximums around $30^{\circ} \mathrm{C}$ and low average temperatures occurred around $10{ }^{\circ} \mathrm{C}$, throughout the period of study. During this period, the duration of the day varied typically from 7 a.m. to 6 p.m. with light intensity. In general, the sky was clear (or not cloudy) with little variation during this period.

The calculated and measured PV cell temperature values show that they will covalue linearly, with a correlation coefficient of more than $87 \%$, as shown in Figure 2 and 3 and $b$. It can be seen from Figures 2, 3, and 4, and from Table 1 that the temperatures of the estimated PV cells show a good correlation with the measured data. The percentage errors are very small. In this analysis, 365 temperature data of the collected PV cells were used. The statistical results above show that the "model" can be used to predict the temperature of the photovoltaic cell with a correlation coefficient of approximately $88 \%$ and an error of $5.25 \%$ for MRL and $4.53 \%$ for PCR. With this new model, one can accurately estimate the temperature of the PV cell for the state of Mato Grosso do Sul.

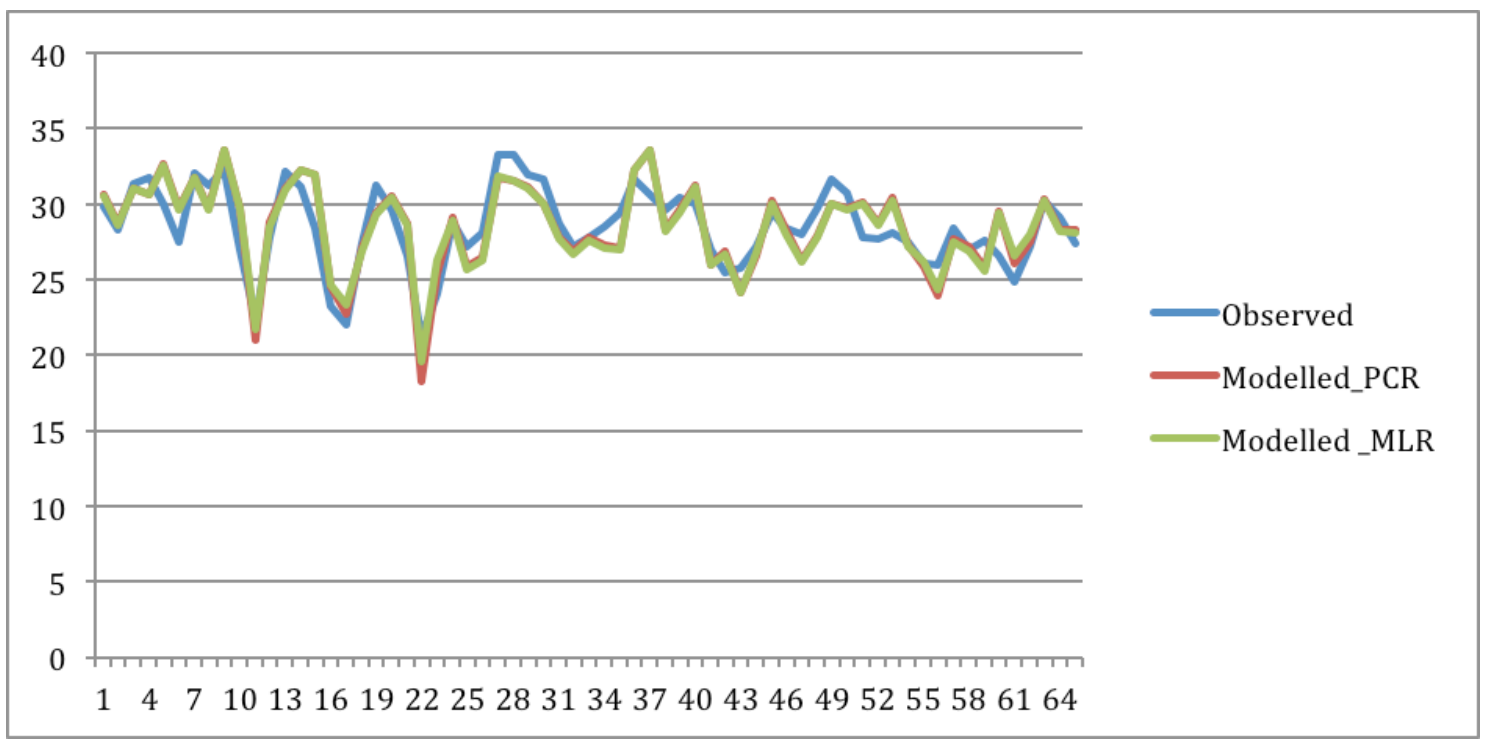

Figure 4. The results of the PCR and MLR modeling for the validation period (last 65 days). 
Muzathik (2014) studied the temperature of the cells from the ambient temperature, irradiance and speed of the wind and found that the model tends to give better results for the temperature of the cells. From the results of the predicted temperatures, it was concluded that the data showed a good correlation with the measured values. Aerosols have characteristics given by the anthropogenic activity in large population centers, since the rural aerosols have particles originated from the vegetal organic activity or even the biomass burning. In the troposphere, the aerosol particles present a short average life, usually of the order of days and weeks, so their spatial distribution is highly nonhomogeneous, being correlated with their emission sources.

Aerosols have a great influence on the climate since they increase the amount of reflected radiation to the space (albedo effect) at the same time as water droplet forming nuclei; they lead to the formation of clouds that help to concentrate the infrared radiation in the troposphere (greenhouse effect). There is also interaction between small diameter aerosols with solar radiation in the spectral region of the visible and near infrared. The size of these smaller particles has the same order as the wavelength of the incident radiation, thus causing the solar radiation to spread. Larger particles have a very low residence time in the atmosphere which means that very large particles (diameter $>15 \mu \mathrm{m}$ ) have low concentrations in the atmosphere. Due to these reasons, the interaction of very large particles with solar radiation is smaller when compared to those of small sizes. However, there are some special cases in which the spreading effects of solar radiation due to these large-diameter aerosol particles can be accentuated. As an example, the occurrence of dust storms and the burning of biomass (quite frequent in Central-Western Brazil and the Amazon Region).
The increase in the concentration of aerosol particles has a fundamental effect on the terrestrial radiative balance (Schafer et al., 2002; Yamasoe et al., 1998; 2000). Aerosols and clouds are basic components in the terrestrial energy balance, although their role is still far from being understood and fully quantified. The so-called direct effect of aerosols on climate consists of mechanisms that directly affect the flux of solar radiation on the surface which can lead to both heating and surface cooling depending on the intrinsic properties of the aerosol particles and surface reflectivity. What happened was a change in the flow of solar energy which affects the temperature profile of the atmosphere.

The main sources of aerosol particles are: soil dust, sulfate (from $\mathrm{SO}_{2}$ oxidation), and emissions from forest fires, among others. The tropospheric aerosols directly affect the radiative balance (absorption and radiation scattering) and/or indirectly (influencing the radiative properties of clouds). Clouds cover about $60 \%$ of the Earth's surface and act on the energy cycle in two ways: the thicker, lower clouds reflect solar radiation back into space, and the higher, thinner clouds transmit solar radiation and at the same time block passage of infrared radiation emitted by the Earth.

The largest sources of aerosols to the atmosphere in South America are emissions from forest and forest fires which occur mainly in the dry season in the Midwest. Brazilian forests and cerrados are regions where biomass burning has historically occurred due to the natural process of land use by farmers and the use of firewood as fuel, but the number of fires has increased significantly in recent years. Observing the seasonal variation of the ozone concentration in the year in Campo Grande, Mato Grosso do Sul, it was observed that this was significantly higher during the months of August and September; end of the dry season. 
The highest concentrations occur coincidently with the months where biomass burning is more intense, associated with low rainfall indexes. However, the same pattern is observed for global solar radiation, extraterrestrial and ultraviolet index and clarity index. There is a significant difference in ozone concentrations between the dry and rainy months. Although, rainfall events are more effective in particulate removal, this behavior is not observed in Campo Grande statistically between the clarity index and the ozone concentration.

The variation of the index of clarity throughout the studied period (from January to December of 2013) is possible to observe the regular behavior of the extraterrestrial radiation with minimum value in June and maximums in the extremes. Already, for the global radiation due to the attenuation suffered by the presence of clouds and others, the curve is irregular; its outline is similar to that of the extraterrestrial radiation. The index of atmospheric limpidity ranged from 0.36 to 0.58 with a mean of 0.51 .

The frequency distribution shows the highest occurrence of clarity index values between 0.36 and 0.58 . According to Kudish and Ianetz (1992), clarity index (Kt) above 0.60 may be representative of clear days. This means that, for the studied city (Campo Grande), the days presented values of kt below 0.60. Days completely overcast, sometimes with rainfall, are characterized by a small limpidity index between 0.01 and 0.30 .

\section{Conclusion}

The total percentage deviation of expected temperature is less than $5.25 \%$ for MRL and $4.53 \%$ for PCR in this study. Therefore, it can be concluded that the predicted temperature accuracy is adequate for renewable solar energy applications and can be used in the study area and in tropical areas with similar climatic conditions where the variables remain relatively constant throughout the day.

Therefore, based on the statistical results, a new simple linear model is recommended to estimate the PV cell temperatures of the research area and in other places with similar areas and equivalent climatic conditions. The present work will help advance the current state of knowledge of renewable photovoltaic solar energy,mainly where the estimation of PV cell temperature has immediate and relevant applications.

The results presented demonstrate that climate modeling is a valuable tool to investigate future changes in PVE productivity. In fact, PVE productivity shows sensitivity to the simulation of different future scenarios and a consistent relationship with projected future changes in climate dynamics. Therefore, while market flexibility and technological development are likely to overcome any potential risk and benefit from climate-induced changes in PVE productivity over the time horizon analyzed in this study, this paper encourages a wider use of climate models in the assessment of the future of ER availability. In addition, an improvement of the climate simulations presents specific for RE applications, for example, the explicit calculation of diffuse irradiation in photovoltaic performance models would be desirable. The importance of policy options for air quality in future climate change and specifically for the future of PVE productivity is also highlighted. In this respect, the use of a state-of-the-art aerosol-climate model can be considered an added value of the present study. In fact, the inclusion of dynamic aerosols in climate simulations is fundamental for a correct evaluation of the climate signal and related PVE productivity because of the impact of aerosols on atmospheric dynamics and radiative balance. 


\section{Conflicts of interest}

Author declares that they have no conflict of interests.

\section{References}

Abdul-Wahab, S. A.; Bakheit, C. S.; Al-Alawi, S. M. Principal component and multiple regression analysis in modelling of groundlevel ozone and factors affecting its concentrations. Environmental Modelling \& Software, v. 20, no 10, p. 1263-1271, 2005. https://doi.org/10.1016/j.envsoft.2004.09.0 01

Albrecht, B. A. Aerosols, cloud microphysics, and fractional cloudiness. Science, v. 245, no. 4923, p. 1227-1230, 1989. https://doi.org/ 10.1126/science.245.4923.1227

Angströem, A. Atmospheric turbidity, global illumination and planetary albedo of the Earth. Tellus, v. 14, p. 435-450, 1962.

Artaxo, P.; Oliveira, P. H.; Lari, L. L.; Pauliquevis, T. M.; Rizzo, L. V.; Pires Junior, C.; Paixão, M. A.; Longo, K. M.; Freitas, S.; Correia, A. L. Efeitos climáticos de partículas de aerossóis biogênicos e emitidos em queimadas na Amazônia. Revista Brasileira de Meteorologia, v. 21, no. 3, p. 168-189, 2006. Available from: <http://www.rbmet. org.br/port/revista/revista_artigo.php?id_art igo=216>. Accessed on: Apr. 24, 2018.

Brasseur, G. P.; Prinn, R. G.; Pszenny, A. A. P. (Eds.). Atmospheric chemistry in a changing world: An integration and synthesis of a decade of tropospheric chemistry research. Berlin: Springer, 2003. p. 125-156. https://doi.org/10.1007/978-3642-18984-5

Crook, J. A.; Jones, L. A.; Forstera, P. M.; Crook, R. Climate change impacts on future photovoltaic and concentrated solar power energy output. Energy and Environmental Science, v. $4, \quad$ p. 3101-3109, 2011. https://doi.org/10.1039/C1EE01495A

Delucchi, M. A.; Jacobson, M. Z. Providing all global energy with wind, water, and solar power. Part II: Reliability, system and transmission costs, and policies. Energy Policy, v. 39, no. 3, p. 1170-1190, 2001. https://doi.org/10.1016/j.enpol.2010.11.045 Denholm, P.; Ela, E.; Kirby, B.; Milligan, M. Role of energy storage with renewable electricity generation. Golden, Colorado:
National Renewable Energy Laboratory, 2010. (Report TP-6A2-47187). Availble from: <https://www.nrel.gov/docs/fy10osti/4718 7.pdf>. Access on: Apr. 23, 2018.

Denholm, P.; Hand M. Grid flexibility and storage required to achieve very high penetration of variable renewable electricity. Energy Policy, v. 39, no. 3, p. 1817-1830, 2011. https://doi.org/10.1016/j.enpol.2011. 01.019

Dowling, P. The impact of climate change on the European energy system. Energy Policy, v. 60 , p. $406-417,2013$. https://doi.org/ 10.1016/j.enpol.2013.05.093

Echer, E.; Souza, M. P.; Schush, N. J. A Lei de Beer aplicada na atmosfera terrestre. Revista Brasileira de Ensino de Física, v. 23, no. 3, p. 276-283, 2001. https://doi.org/ 10.1590/S1806-11172001000300004

El-Chaar, L.; Iamont, L. A.; El-Zein, N. Review of photovoltaic technologies. Renewable Sustainable Energy Review, v. 15, no. 5, p. 2165-2175, 2011. https://doi.org/10.1016/ j.rser.2011.01.004

Feuermann, D.; Gordon, J. M. Highconcentration photovoltaic designs based on miniature parabolic dishes. Solar Energy, v. 70, no. $5, \quad$ p. $423-430,2001$. https://doi.org/10.1016/S0038-092X(00) 00155-9

Hansen, J.; Sato, M.; Ruedy, R. Radiative forcing and climate response. Jounal of Geophysical Research, v. 102, no. D6, p. 6831-6864, 1997. https://doi.org/ 10.1029/96JD03436

Holben, B. N.; Eck, T. F.; Sluysker, I.; Tanré, D.; Buis, J. P.; Setzer, A.; Vermote, E.; Reagan, J. A.; Kaufman, Y. J.; Nakajima, T.; Lavenu, F.; Jankowiak, I.; Smirnov, A. AERONET: A federated instrument network and data arquive for aerosol characterization. Remote Sensing of Environment, v. 66, no. 1, p. 1-16, 1998. https://doi.org/10.1016/ S0034-4257(98)00031-5

IPCC - Intergovernmental Panel on Climate Change. Special report on renewable energy sources and climate change mitigation: Summary for policymakers. Cambridge: Cambridge University Press, 2011.

Jacobson, M. Z.; Archer C. L. Saturation wind power potential and its implications for wind energy. PNAS, v. 109, p. 15679-15684, 2012. https://doi.org/10.1073/pnas.1208993109 
Jacobson, M. Z.; Delucchi, M. A. Providing all global energy with wind, water, and solar power. Part I: Technologies, energy resources, quantities and areas of infrastructure, and materials. Energy Policy, v. 39, no. 3, p.1154-1169, 2011. https://doi.org/10.1016/j.enpol.2010.11.040 Jordan, D. C.; Kurtz, S. R. Photovoltaic degradation rates: An analytical review. Progress in Photovoltaics, v. 21, no. 1, p. 12-29, 2013. https://doi.org/10.1002/ pip.1182

Kloster, S.; Dentener, F.; Feichter J.; Raes, F.; Aardenne, J.; Roeckner, E.; Lohmann, U.; Stier, P.; Swart, R. Influence of future air pollution mitigation strategies on total aerosol radiative forcing. Atmospheric Chemistry and Physics, v. 8, p. 6405-6437, 2008. https://doi.org/10.5194/acp-8-6405-2008

Kloster, S.; Dentener, F.; Feichter, J.; Raes, F.; Lohmann, U.; Roeckner, E.; Fischer-Bruns, I. GCM study of future climate response to aerosol pollution Reductions. Climate Dynamics, v. 34, no. 7/8, p.1177-1194, 2010. https://doi.org/10.1007/s00382-0090573-0

Kudish, A. I.; Ianetz, A. Analysis of the solar radiation data for Beer Sheva, Israel, and its environs. Solar Energy, v. 48, no. 2, p. 97-10, 1992. https://doi.org/10.1016/0038-092X (92)90038-C

Latorre, M. R. D. O.; Cardoso, M. R. A. Análise de séries temporais em epidemiologia: uma introdução sobre aspectos metodológicos. Revista Brasileira de Epidemiologia, v. 4, no. 3, p. 145-152, 2001. https://doi.org/ 10.1590/S1415-790X2001000300002

Montgomery, D. C.; Peak, E. A. Introduction to linear regression analysis. 2. ed. New York: Wiley \& Sons, 1992.

Montogomery, D. C.; Peck E. A.; Vining G. G. Introduction to linear regression analysis. 3. ed. New York: John Wiley \& Sons, 2001.

Muzathik, A. M. Photovoltaic modules operating temperature estimation using a simple correlation. International Journal of Energy Engineering, v. 4, no. 4, p. 151-158, 2014.

Olsen, R. L.; Chappell, R. W.; Loftis, J. C. Water quality sample collection, data treatment and results presentation for principal components analysis: Literature review and Illinois River watershed case study. Water Research, v. 46, no. 9, p. 3110-3122, 2012. https://doi.org/10.1016/j.watres.2012.03.02 8

Parida, B.; Iniyan, S.; Goic, R. A review of solar photovoltaic technologies. Renewable Sustainable Energy Review, v. 15, p. 16251636, 2011. https://doi.org/10.1016/ j.rser.2010.11.032

Pašičko, R.; Branković, Č; Šimić, Z. Assessment of climate change impacts on energy generation from renewable sources in Croatia. Renew Energy, v. 46, p. 224-231, 2012. https://doi.org/10.1016/j.renene. 2012.03.029

Patt, A.; Pfenninger, S.; Lilliestam, J. Vulnerability of solar energy infrastructure and output to climate change. Climate Change, v. 121, no. 1, p.93-102, 2013. https://doi.org/10.1007/s10584-013-08870

Pires, J.; Martins, F.; Sousa, S.; Alvim-Ferraz, M.; Pereira, M. Selection and validation of parameters in multiple linear and principal component regressions. Environmental Modelling \& Software, v. 23, no. 1, p. 50-55, 2008. https://doi.org/10.1016/j.envsoft. 2007.04.012

Raes, F.; Seinfeld, J.H. New directions: Climate change and air pollution abatement: A bumpy road. Atmospheric Environment, v. 43, no. 32, p. 5132-5133, 2009. https://doi.org/10.1016/j.atmosenv.2009.06 .001

Razykov, T. M.; Ferekides, C. S.; Morel, D.; Stefanakos, E.; Ullal, H. S.; Upadhyaya, H. M. Solar photovoltaic electricity: Current status and future prospects. Solar Energy, v. 85, no. 8, p. 1580-1608, 2011. https://doi.org/ 10.1016/j.solener.2010.12.002

Ricieri, R. P. Modelos de estimativa e avaliação dos métodos de medida da radiação solar difusa. Botucatu: Universidade Estadual Paulista "Júlio de Mesquita Filho", Faculdade de Ciências Agronômicas, 1998. (Thesis).

Roeckner, E.; Bengtsson, L.; Feichter, J.; Lelieveld, J.; Rodhe, H. Transient climate change simulations with a coupled atmosphere-ocean GCM including the tropospheric sulfur cycle. Journal of Climate, v. 12, p. 3004-3032, 1999. https://doi.org/10.1175/1520-0442(1999) 012<3004:TCCSWA >2.0.C0;2

Ryu, K.; Rhee, J.-G.; Park, K.-M.; Kim, J. Concept and design of modular Fresnel lenses for concentration solar PV system. 
Solar Energy, v. 80, no. 12, p. 1580-1587, 2006. https://doi.org/10.1016/j.solener. 2005.12.006

Schaeffer, R.; Szklo, A. S.; Lucena, A. F. P.; Borba, B. S. M. C.; L. Nogueira, P. P.; Fleming, F. P.; Troccoli, A.; Harrison, M.; Boulahya, M. S. Energy sector vulnerability to climate change: A review. Energy, v. 38, p. 1-12, 2012. https://doi.org/10.1016/j.energy. 2011.11.056

Schafer, J. S.; Holben, B. N.; Eck, T. F.; Yamasoe, M. A.; Artaxo P. Atmospheric effects on insolation in the Brazilian Amazon: Observed modification of solar radiation by clouds and smoke and derived single scattering albedo of fire aerosols. Journal of Geophysical Research, v. 107, no. D20, p. LBA-41-1-LBA-41-15, 2002. https://doi.org/ 10.1029/2001JD000428

Si, F. T.; Isabella, 0.; Zeman, M. Thin-film amorphous silicon germanium solar cells with $\mathrm{p}$ - and n-type hydrogenated silicon oxide layers. Solar Energy Materials and Solar Cells, v. 163, p. 9-14, 2017. https://doi.org/10.1016/j.solmat.2017.01.00 1

Skoczek, A.; Sample, T.; Dunlop, E. D. The results of performance measurements of field-aged crystalline silicon photovoltaic modules. Programs in Photovoltaics, v. 17, p. 227-240, 2009. https://doi.org/10.1002/ pip.874

Skoplaki, E.; Palyvos, J. A. On the temperature dependence of photovoltaic module electrical performance: A review of efficiency/power correlations. Solar Energy, v. 83, p. 614-624, 2009. https://doi.org/10.1016/j.solener. 2008.10.008

Souza, A.; Aristone F.; Sabbah I. Modeling the surface ozone concentration in Campo Grande (MS)-Brazil using Neural Networks. Natural Science, v. 7, no. 4, p. 171-178, 2015. https://doi.org/10.4236/ns.2015.74020

Souza, A.; Aristone, F. Estudo da eficiência energética de células fotovoltaicas em função da radiação solar no Centro-Oeste Brasileiro. Interespaço: Revista de Geografia e Interdisciplinaridade, v. 2, p. 115-128, $2017 . \quad$ https://doi.org/10.18764/24466549.v2n7p115-128

Souza, A.; Aristone, F. Um estudo da temperatura e da irradiação solar em células fotoeletricas. Tecno-Lógica, v. 22, p. 194200, 2018. http://doi.org/10.17058/ tecnolog.v22i2.11378
Souza, A.; Aristone, F.; Ferrari, L. F.; Reis, R. R. Modelling of the photovoltaic cell temperature according to the ambient temperature, wind speed and solar irradiance. Revista Brasileira de Energia, v. 5, p. 504-518, 2016.

Souza, A.; Pavão, H. G.; Oliveira, A. P. G. Modeling of ozone due to weather conditions. Revista Brasileira de Climatologia, v. 12, p. 8-21, 2013. http://doi.org/10.5380/ Abclima.V12i1.29648

Trinuruk, P.; Sorapipatana, C.; Chenvidhya D. Estimating operating cell temperature of BIPV modules in Thailand. Renewable Energy, v. 34, no. 11, p. 2515-2523, 2009. https://doi.org/10.1016/j.renene.2009.02.0 27

Twomey, S. The influence of pollution on the shortwave albedo of clouds. Journal of Atmospheric Sciences, v. 34, p. 1149-1152, $1977 . \quad$ https://doi.org/10.1175/15200469(1977)034<1149:TIOPOT>2.0.C0;2

UNECA - United Nations. Economic Commission for Africa. Integrating renewable energy and climate change policies: Exploring policy options for Africa. UNECA African Climate Policy Centre, 2011. (Working paper, no. 10).

Vermote, E. F.; Vermeulen A. Atmospheric correction algorithm: Spectral reflectances (MOD09). NASA, 1999. (Algorithm theoretical background document). Available from: <https://eospso.nasa.gov/sites/ default/files/atbd/atbd_mod08.pdf>.

Acessed on: Apr. 25, 2018.

Wachsmuth, J.; Blohm, A.; GößlingReisemann, S.; Eickemeier, T.; Ruth, M.; Gasper, R.; Stührmann, S. How will renewable power generation be affected by climate change? The case of a Metropolitan Region in Northwest Germany. Energy, v. 58, no. 1, p. 192-201, 2013. https://doi.org/10.1016/ j.energy.2013.06.035

Wu, Y.; Eames, P.; Mallick, T.; Sabry, M. Experimental characterization of a Fresnel lens photovoltaic concentrating system. Solar Energy, v. 86, p. 430-440, 2012. https://doi.org/10.1016/j.solener.2011.10.0 32

Yamasoe, M. A.; Artaxo, P.; Miguel, A. H.; Allen, A. G. Chemical composition of aerosol particles from direct emissions of biomass burning in the Amazon Basin: Water-soluble species and trace elements. Atmospheric Environment, v. 34, p.1641-1653, 2000. 
https://doi.org/10.1016/S1352-2310(99)

00329-5

Yamasoe, M. A.; Kaufman, Y. J.; Dubovik, O.; Remer, L. A.; Holben, B. N.; Artaxo, P. Retrieval of the real part of the refractive index of aerosols from sun/sky radiometers during SCAR-B. Journal of Geophysical Research, v. 103, no. D24, p. 31893-31902, 1998. https://doi.org/10.1029/98JD01211 original work is properly cited. 